\title{
Determinants of Employee Turnover A Survey of Employee Intentions Trend in Urban Societies of the Region
}

Roohi Mumtaz ${ }^{1 *}$ and Syed Shahwar Hasan²

1Department of Commerce and Management, Al Falah University, Al Gharhoud, Dubai, UAE

${ }^{2}$ Assistant General Manager, Indus Motors Ltd., Karachi, Pakistan

\begin{abstract}
The banking sector in the south Asian region has witnessed considerable turnover rate with the turn of millennium and simultaneously generating plenty of attractive job opportunities springing up in external markets for the employees. Every organization makes all efforts to retain its valuable workforce to lead and sustain in the trade market and prosper in the corporate world. The focus of this research paper was to identify the motives and the determinants of increasing rate of employee turnover. This would further lead to their work relationships that unfold their aims and intentions that materialize them motivates in switching jobs. The prime focus of this research paper was the urban society of the region and highlights the determinants and reasons behind that increase the rate of turnover. The determinants discussed in the research study include employee-boss relations, job satisfaction, organizational commitment, gender discrimination and the apparent job opportunities.

The primary as well secondary sources of research were used to gather the information. Primary research includes the survey questionnaires which were prepared to gather factual data for the purpose. The simple random sampling method which is a type of probability sampling method was used to select the sample from the different leading Banks of the urban areas of Karachi. The study has found strong positive correlation between the employeeboss relations and employee turnover. The secondary determinants such as, job contentment and job commitment show modest and pessimistic relationship in employee turnover while lucrative job opportunities have strong positive and direct correlation with employee turnover.
\end{abstract}

Keywords: Employee turnover; Job satisfaction; Employee-boss relation; Opportunities; Pakistan; Banking sector

\section{Introduction}

The heat of change and scenarios within the corporate world, trade and businesses changed themselves altogether. Not only the approaches being changed, but also the environment and attitudes toward work is also changed. The work handling procedures and to facilitate the employees has also gone through many phases and strokes of change. In order to take out best out of them and to retain their workers and employees with great motivation and in order to fulfil their long term objectives, they switched to employ new short term strategies. These strategies addresses not only how to cope up with difficulties of productions, operations but also to take care and addresses the employees grievances, their facilities and other benefits.

Flood of globalization and change not only produce stream of stimuli that changes the perception and standings of employees but also hit very badly to the businesses and local markets all over the world. It has made and change life for employees, management, environment, businesses and organizations altogether. Every change has some good and adverse effects. In the challenging heat change and stressful impact globalization, where organizations have to compete and meet the demand and supply, quality and reputation and to satisfy the consumers need and demand, they also need to satisfy the demand and needs of the employees and workers to retain them. To retain these employees, job satisfaction, organizational commitment, apparent job opportunities and employee-boss relations are among the important factors to address. There are number of tasks to overcome with respect to globalization like economic recession, employee turnover, competitive environment and open access to external markets etc.

The world today is a global village resulting to new businesses and chains of enterprises opening all over to spread their business in the open market. The effect of this revolutionary development is competitive environment emerging for both the local and external market. Due to this, plenty of new job opportunities are available for the employee's simultaneously creating challenges for employers where turnover rate also increases all over the world. A related consequence can also be seen in Pakistan, as well as organizations and industries face the undesirable insinuations of it at all level. There are many frequent and other reasons as well for these high turnover trends of employees in Pakistan that has made it more complicated for top management and owners to keep their skilled and desirable workers intact. The prime issue in this regard is to minimize the turnover rate after critically examination of the reasons behind. It is essential to find out the major determinants of the workforce turnover where employee intentions have become detrimental for the organizations and to have the strong surrogate indicator for such behaviour in Pakistani urban society.

Change is unavoidable; however it can affect businesses adversely. Leaving of employees for any reason is the sign of change that can pessimistically exert its impact on the root line of the organization. To retain the valuable employees within the organization for longer period of time and to know the exact motives of leaving, management must need some special retention strategy and attention. Leaving of employees from the organization can be of many reasons and to keep their interest intact one has to work hard in this respect.

*Corresponding author: Mumtaz R, Department of Commerce and Management Al Falah University, Al Gharhoud, Dubai, UAE, Tel: +971 4233 8063; E-mail: roohi.imtiaz@afu.ac.ae

Received April 20, 2017; Accepted May 30, 2018; Published June 06, 2018

Citation: Mumtaz R, Hasan SS (2018) Determinants of Employee Turnover A Survey of Employee Intentions Trend in Urban Societies of the Region. Bus Eco J 9: 356. doi: 10.4172/2151-6219.1000356

Copyright: (c) 2018 Mumtaz R, et al. This is an open-access article distributed under the terms of the Creative Commons Attribution License, which permits unrestricted use, distribution, and reproduction in any medium, provided the original author and source are credited. 
The major trend of leaving jobs is supposed to be the immediate head and subordinate relations. The level of coordination in this respect is sensitive. Subordinates always look at their bosses for all cooperation and if this relationship disturbed by somehow then they have hardly any other option left to choose. In this case their loyalty towards their job, responsibilities, and duties and towards goal and organization become feeble and blurred and they feel it better to move ahead towards new opportunities.

The other reason of the workers or employees to move ahead for opportunities is the lack of commitment and low level of job satisfaction towards their responsibilities, duties and organization in large. Job contentment according to lvancevich et al. [1] is the insight of the worker and their feelings about the work and attitude towards organization. Feeling satisfied with job is the experience and exposure of employees to different grievances difficulties and work related issues and the work related atmosphere the come across [2]. The discussion on job contentment that leads to employee turnover has been extensively found in the literature of organizational behaviour allround the globe. The debate leads this discussion towards the positive end where management found many of the hidden truths in order to curtail the turnover rate and absenteeism of the employees from their duties and job.

It has also been observed in the urban society of Pakistan that if the employee's level of commitment towards job minimises, the chances of their switching of job maximises. Retaining the smart and skilled employees and their commitment towards the organization is an arduous task however it would bring high performance delivery from the employees along with the quality improvement, improvised succession planning that ultimately result in consumers satisfaction, reputation and status improvisation of the organization. This will not stop here; in fact this achievement will lead and motivate other employees to work harder and improvise their skills, qualification and learning abilities who are working beneath and as colleagues to those high achievers. Analytical reviews of turnover intentions among the professionals of banking sector in Pakistan are specified along with the factors that noticeably provide ease to it.

\section{Literature Review}

The companies and the administration all over the world demonstrate their intense attention in retaining their talented and smart employees and spend inordinate agreement of efforts to gratify them regarding their job and working environment. The scenario varies among between regions and economies depending upon their level of economic development, culture, tradition etc. The situation is quiet diverse and embellished in Pakistan in comparison to other entities of the region. Factors like law and order situation, severe power and energy crises, high inflation rate and mostly add up to lead an employee to leave the current job for better prospects and wellbeing.

These factors are becoming increasingly influential in jobs turnover decisions in recent years. Occasionally these types of things turn to be damaging for the organization's wellbeing and success. The employees when interchanging the organisation leave several questions for the organization to suffer the consequences. These firms often have to discover the finest alternate to replace the operative immediately, which could only happen if they have the proper and well-organized succession planning within the organization. These updates of succession planning is quiet helpful for them to incorporate the post soon after it is vacant.
Organizations invest majority of things to motivate and provide expertise to their employees. Some of them are like providing guidance, possible training opportunities, provides exposure, and every opportunity to groom them professionally and personally. In order to maintain and retain them in their organization they give their employees to develop themselves as valuable asset. Therefore, managers at all costs must minimize employee's turnover. Although, there is no hard and fast rule or set standard or charter to know the reason of why employees switch or leave their jobs. In order to evaluate the whole process of change and turnover factors, some of the factors have been found very interesting in this regard for interpretation [3].

In order to have a comprehensive research study of employees leaving or switching job factors and minimize to this consequences, we need to examine the most prominent factors closely that affects adversely everyone in the organization. The invasion of globalization to the world of business and trade, provide every organization to develop tangible product with some practical strategies and need to be created by employees. These employees are the asset of the organization as they are the most capable and trust worthy people and cannot be easily replaced or replicated [4].

Consequently, management acknowledge that employees are the main contributor of what organization is striving and trying to achieve. Their effectiveness and efficiency can bring them to zenith and vice versa [5]. Management need to control the absenteeism and turnover rate for organizational success and prosperity. The factors of the employee's turnover are separated in three distinct parts; sources of employee turnover, effects of turnover and the strategies to minimize turnover.

The crucial employee-boss relationship usually stimulates the desire within an employee to switch or stick to the current job. This factor proved as the most important and vital factor in the findings of the research and that can leads a capable worker to become demotivated, think and switch his job. This switching of job is not just a switch but it has great repercussions and consequences afterwards. So the switching of jobs or absenteeism observed mostly due to unavoidable behaviour and attitudes of the bosses especially immediate boss of an employee.

The researchers in the previous decades have also tried to reply the answers of what are the root instigating points to quit a job [6-9]. The other determinants and factors were highlighted by those researchers in previous ages. Many reasons have been identified in the findings of the research that why people left their jobs. The most prominent among the factors are lack of commitment people have with their duties and responsibilities, they become dissatisfied with the environment, behaviour and attitude shown by the bosses and colleagues, and job related stress that take their nerves high on different matters [10].

In any organization it is believed that the main source of motivation and inspiration comes from the leaders. These leaders play crucial role in building and increasing the employees effectiveness, efficiency and this will also increase the trust of the employees toward the organization, their commitment and provide them immense job satisfaction $[11,12]$. The employees when enter into the organization as fresh entrants, it the leader who nurtured them and provide them every guidance support, opportunity and exposure to developed as valuable assets for the organization. However if not, then the consequences lead organizations and employees towards failure and depression. These consequences most of the time, actually instigate the thought of switching or leaving the job, responsibility and commitment from the organization. If fingered out the situation well then it converts one 
of the vital motives to lessening the rate of turnover aims within the employees.

Researchers perceived and viewed through different studies and reviews that employees usually negotiate on the issues like work handling problems, security, issues with peers' compensation and benefits issues. There is hardly any evidence seen that people negotiate on the issues related to their immediate boss and relationship. This very interesting to give statement that most of the people leave their existing jobs because they do not share good relations with their superiors and have to face inappropriate behaviour and many consequences if they do not leave.

Extensive studies have been conducted on improved turnover rate by Khatri et al. [13]. The samples from food and beverages industry, shipping and marine and retailing industry made it possible to conduct research on the topic. The research findings concludes that aims or interest of switching from jobs were found high in managerial position rather than people working on non-managerial positions. The studies were conducted on professional accountants in Singapore and on IT professional in 2005 by Khatri et al. [13]. The result showed negative relations with that of employee turnover intentions and job contentment [14].

The pessimistic relation found in research studies regarding turnover intentions and job contentment. The study on organizational conflict, employee turnover and job satisfaction rate and the relationships between them was also conducted [15]. Studies on internal auditors also showed great significance and pessimistic relations in this respect [16]. The research was conducted on career management, job contentment and employee turnover intentions that showed the pessimistic correlation between job contentment and employee turnover. Job contentment has been observed to be a strong negative factor of employee turnover [17].

Job contentment is multi facet in nature. The factors revolves round to it are leading the work and supervising appropriately, own job, rewards and benefits attached and policies to give promotions and incremental salaries, assessment and evaluation of employees and attitude of the workers and bosses [18]. Commitment to organization and employees satisfaction with their jobs plays a very important and decisive role in turnover desire and intention [19]. Satisfaction level of the employees can be measured by their work handling, procedures they follow, attitude towards work, peer, subordinates and responsibilities etc. when employees are satisfied enough from their job and position, it translated through their work, behaviour and attitude they show. Guimaraes and igbaria argued that the impact of job satisfaction and commitment with the organization are reciprocal to turnover intentions [20]. Some other work has been observed in the same line of action that job satisfaction and commitment towards job are the main and vital ingredients of employee turnover [21].

Van et al. in research observed that Job contentment was the predictor of the employee turnover intentions [22]. They also added that the employee turnover intentions only materialized when there is lack of satisfaction and commitments towards the organization. Some of the other researcher added to this knowledge like the studies of Sjoberg and Sverke [23]. They explained the above concept in detail and elaborated the idea that how commitment and satisfaction towards job nourishes and turnover is basically an outcome if anything not went good [23]. Another researcher Morrison explained the same concept in different style. He argued and took this idea to one more level up by saying that there is a negative correlation found between commitment and satisfaction of job with that of employee turnover aims [24].

Keeping in view of all the work and research done on factors associated to satisfaction of work, it was observed that contentment of job is directly related to improved productivity and they have very close connection to each other. The improved production and technological advancement are interdependent on each other. There are other factors like wealth inflows, variations in strategies, plan and policies and other resources also play vital role in enhancement of production. Apart from all these factors, human resource management, their practices, strategies and involvement also considered as the most crucial ingredient in improved productivity.

They have the ability to spin the whole game of production and achievement of goals like any other important factor does in enrichment of production [25]. Sels et al. in research study argued that the best practices of human resource management can beat the turnover aims of employees [26]. The enhanced productivity achieved and employees and workers hardly thought of leaving the organization because the involvement and commitment shown by human resource management with respect employees problems, grievances, security, compensation and wages packages etc.

All the research and studies in this regard have agreed that when employees are satisfied with their jobs and organization, production in the organization will always be enhanced because the employees feel motivated and satisfied the way they have been given treated and nurtured in the organization [27]. Above all the studies and arguments, this is true that every manger does their best to connect closely to their valuable employee and never wanted to lose them at any cost. They took every precaution and possible steps in order to retain them. It has been observed that for retention of effective and efficient employees, they will also sometimes fight with the management.

Satisfaction towards work, commitment with duties and responsibilities are not only the factors discussed by the researchers that instigate the intentions of turnover among employees and workers. The factor like organizational commitment has the same importance as far as turnover rate is concerned. It has been shown through in-depth studies that if employees are not committed to their job and organizations, they failed to be claim as valuable resources of the organization. The factor of organizational commitment is also included as the part of this research study as independent variable in order to validate the hypothesis in relation to turnover intentions.

The researchers have earlier conducted the research studies on Japanese executives and workers to prove the relation of turnover intentions with that of organizational commitment [28]. The researcher took the job commitment as the independent variable with respect to turnover intentions. They explained in that if the level of commitment towards the job and organization is greater, the level of intentions to switch or leave the job is low and due to this it is observed that the employees feel happy and motivated. These factors reciprocate each other. Samad in another study argued that these two factors are linked together pessimistically [29].

In other research study, the researcher focussed on the factors of job or organizational commitment with that of the turnover aims and their relations [30]. They studied on how they affect each other if any one of the factor show minimum rate of interest. This research was conducted on the sales personnel however the result showed that very little or no relation with respect to turnover intentions and there was no or traces of impact found. Elangovan [31] has discussed his studies 
with respect to the same relation and found the relation as reciprocal. His findings were entirely different from the findings of Moncrief and his associates in this study, the researcher found that there is an indirect connection exists between commitment of an employee towards his job and turnover aims.

Apart from job satisfaction, boss and employee relations and commitment of an employee towards his job and organization, job opportunities also act as important factor to play in the game of turnover intentions of the employee. As depicted from the name, who doesn't want to get good opportunities in life? This determinant has great value and impact on the aims of employee turnover rate. Skilled, talented, capable effective and efficient employees have greater chances to get and grab those opportunities to advance and boost their careers. In that case if these employees feel themselves as less important, less secure and less packages and chances to grow, they immediately switch to some better place and grab the opportunity as it comes.

Sometimes it happens that the companies and organizations themselves search for those valuable and skilled employees. They make separate departments in which their employees constantly busy in intensive kind of research in order to find capable employees. They closely outline their requirements and employee's capabilities who can work for them and in return groom themselves more as better and successful professional. In this kind of situation, it is really hard for the companies to retain their valuable asset. They have to offer extra attractive perks and advantages in order to keep them intact. Although, it seems very difficult to keep the employees remain motivated and intact with their jobs and organization for longer period of time, as this era belongs to open market and globalization, where the demand of the capable employees and workers are at its height [32].

The positive relations found between the employees aims to either switch or leave their jobs and the opportunities of job. These relations were the findings of the research study conducted in this regard by lngSan Ing-sang and Jyh-Huei [33] another research was conducted on the same determinants and shared the results of the study as optimistic and direct [34]. Similar kind of research study also conducted by another set of researcher who also found the same result after thorough study on the determinants of turnover and job opportunity [35]. However the pursuance has been observed as negative on employee turnover aims.

There is a list of other reasons also why people leave their jobs. Like for example employees leave their jobs due to the feeling of powerlessness, some of the external factors that can influence their lives altogether and do not want that Firth et al. [10]. Some of the researchers believe that employees leave their jobs because they need more money, incentives and sometimes whatever they have been given as a salary or benefits are not enough to fulfil their expenses. Good local labour market can bring strength and stability to the organization [36].

In multinational organizations and large organization provide their employees good opportunities to explore their skills and capabilities and groom them as required to advance professionally and personally too. In this case they not only advance in their career but they also make themselves able to have excellent salary packages and benefits and feel the attachment sentiments with the organization [37]. The redundancy ratios directly interact with the job contentment and that will forecast the turnover rate in the market [38]. The turnover sometimes happened as voluntary and sometimes it happened as involuntary. Some of the contemporary approaches in today time in which sometimes government regulations, rules and policies create the opportunities for those employees who left their jobs or went on long leaves. They have this opportunity to work on more flexible terms than before [39]. However this is noticeable that employees remain do their work with great commitment and enthusiasm when they observe and experience the favourable environment and vice versa [40].

The employees are more likely to attach with the organization having very clear and manageable goals. The restriction in hiring certain numbers of employees also led to uncertain situation and ultimately results in high turnover rate [39]. These kinds of approaches need to be avoided in order to minimize the turnover rates. Another factor that needs to be highlighted that researchers observed that communication among and between the employees are very important in order to reduce the turnover ratios. In active communication scenario, where employees are given chance to share the feedback of how they see and feel with any of the new or alteration has been made anywhere in the organization. There is a sense of responsibility and feeling of importance [41]. In these cases employees relax and satisfied with their contributions in terms of work responsibilities and being involved in the decision making process at some level. Employees are smart enough to know their importance and consequences of work and environment, if they will leave [42-44].

\section{Hypothetical Structure}

In order to find out he determinants that instigate the process of turnover intentions among the workers and employees, this research was conducted. In order to know their relations and the degree to which they depend on each other was the main aim of this study. Through research it has been observed that different determinants play crucial role in order to influence the turnover aims of employees. The turnover ratios in urban society of Pakistan in different fields of expertise are extremely high. Research conducted in European and American entities and environment were discussed in the literature. There were four hypothetical structure discussed in this study. Work satisfaction, boss and subordinate relations, work commitment and work opportunity. The findings of the research to support the study are as follows;

H1: Negative employee-boss relationship leads to high turnover intentions.

H2: Pessimistic correlation between employee turnover intentions and job satisfaction.

H3: Work commitment and employee turnover have optimistic effect on organizational productivity.

H4: Attractive work prospects have positive impact on employee turnover rate.

Given below is the model of hypothetical structure that shows the association of different determinants with that of the turnover intentions of the employees (Figure 1).

\section{Methodology}

The study aims to found the relations of different variables and this study was conducted on the professionals of banking sector. The primary as well secondary sources of research were used to gather the information. Primary research includes the survey questionnaires which were prepared to gather factual data for the purpose. The simple random sampling method which is a type of probability sampling method was used to select the sample from different leading Banks of the urban area. The sample size of the respondents is around 500 out of which 355 was successfully received. The sample was collected from 


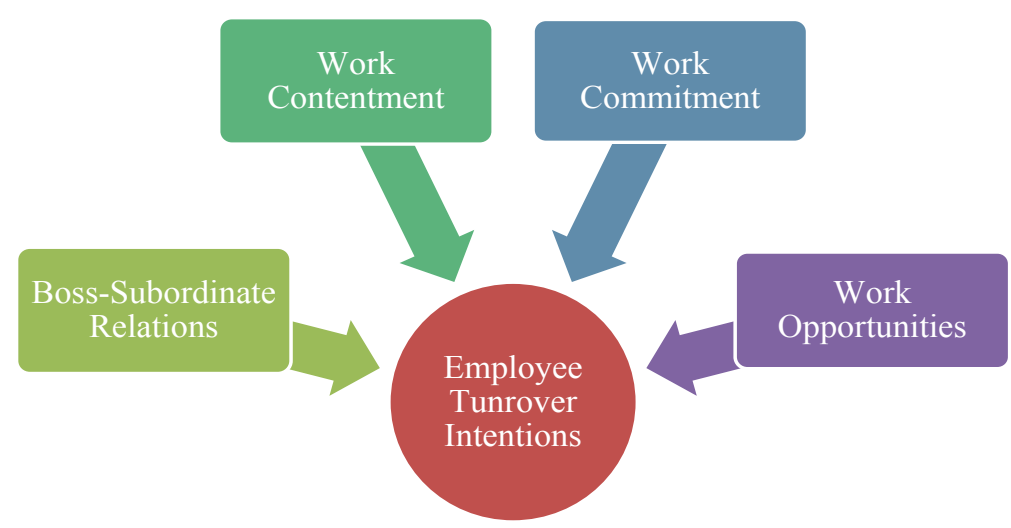

Figure 1: Model of correlations between Independent variables and Dependent variables.

the people of different hierarchal positions and post of varied branches of banks working in Pakistan. The survey was based on questionnaires and data was collected from the branches of Bank Alfalah, UBL, ABL NBP, Meezan Bank Ltd. Dubai Islamic Bank Faysal Bank and Standard Chartered Bank. The questionnaires are composed on the variables and their relationship with each other in order to measures the turnover aims of employees.

The respondents were briefed about the aims of survey and there were no right or wrong option. Those were designed how they feel about the turnover intentions and what was their opinion about the variables affecting the intentions of turnover? Those respondents were reassured of the confidentiality of this research. In order to collect information and data secondary sources also used like desktop research, books, research articles etc. The results of the survey and findings are given below.

\section{Results}

The survey questionnaires distributed in varied branches of the Banks located in different places. So we divided the sample demographically, age, education, nature of job, level of income and years in Bank service. The greater number of respondents belongs to the age groups between 20-30 years i.e., 252. In comparison the least number of respondents belongs to age groups between 50 years or above. Most of the respondents were having master's degree and only $5.64 \%$ of the respondents were having education till M. Phil level. The respondents mostly associated to managerial jobs and were holding junior level post and the least number of respondents hold area manager positions (Table 1).

\section{Hypothesis testing}

H1: Boss-subordinate conflict leads to high turnover rate: The most crucial relationship with respect to effective and ineffective work bonding between boss and his immediate subordinate depends on the relationship they share. The issue might arise because of personality, behaviour, attitude irrational support and giving undue favours. Usually these kinds of issues are very common among the organizational set up. However, the employees' compromise on many other problems exists within the organization but they hardly agree to compromise on this issue. The effect of their problems directly exerts its impact on employee performance, goal attainment and production of the organization. These consequences ultimately lead towards ill performance, unsuccessful in achieving goals and blur future prospects which results in greater turnover rate of the employees.

\begin{tabular}{|c|c|c|c|}
\hline Demographics & Category & Numbers & Percentage \\
\hline \multirow[t]{4}{*}{ Age } & $20-30$ & 252 & $70.98 \%$ \\
\hline & $31-40$ & 81 & $22.81 \%$ \\
\hline & $41-50$ & 17 & $4.78 \%$ \\
\hline & 50 or Above & 5 & $1.41 \%$ \\
\hline \multirow[t]{3}{*}{ Education } & Bachelors & 110 & $30.98 \%$ \\
\hline & Masters & 225 & $63.38 \%$ \\
\hline & M.S/M.Phil. & 20 & $5.64 \%$ \\
\hline \multirow[t]{4}{*}{ Nature of Job } & Area Managers & 17 & $4.78 \%$ \\
\hline & Sr. Managers & 43 & $12.11 \%$ \\
\hline & Jr. Managers & 223 & $62.81 \%$ \\
\hline & Staffs & 72 & $20.28 \%$ \\
\hline \multirow[t]{4}{*}{ Income Level } & Below-Rs.30,000 & 72 & $20.28 \%$ \\
\hline & Rs. $30,001-R s .60,000$ & 219 & $61.69 \%$ \\
\hline & Rs. $60,001-R s .90,000$ & 45 & $12.67 \%$ \\
\hline & Rs. 90,000 or Above & 19 & $5.36 \%$ \\
\hline \multirow[t]{4}{*}{ Years in Bank } & Less than a year & 108 & $30.42 \%$ \\
\hline & $1-5$ years & 98 & $27.61 \%$ \\
\hline & $6-10$ years & 138 & $38.88 \%$ \\
\hline & 11 or above & 11 & $3.09 \%$ \\
\hline
\end{tabular}

Table 1: The survey questionnaires distributed in varied branches of the Banks located in different places.

Findings: The study of this research survey questionnaire has shown optimistic relations between the boss-subordinate. The coordination between these two is very crucial in context of the organizational success. Even a minor type of conflict between them leads to high turnover aims among the employees. According to the survey, about $98 \%$ of the respondents of age, $91 \%$ of the education, $89 \%$ of the job, $95 \%$ of the income level and $95 \%$ of the experience group agree with the questions asked. For the second question, about $91 \%$ of age, $88 \%$ of education, $75 \%$ of the job, $82 \%$ of the income level and $77 \%$ of the experience group agree with the question asked. No or very rare compromises and disagreement have been seen on this particular issue and therefore it powerfully prove the assumption correct.

H2: Pessimistic correlation between employee turnover inventions and work satisfaction

The intentions shown by the employees to change their jobs or to quit may be because of many reasons. They usually worried about their future prospects, career and advancing professionally. As per the survey Questionnaire showed that unskilled workers and employees might lose their jobs or they fail to retain their position in the organization. 
In comparison to this, company or organization has shown their keen interest in retaining those employees who are very talented, capable, effective and efficient in their performance and work. The satisfaction level of these employees was usually at its peak. The determinant behind this is the care and support from the top management. In this scenario the employers succeeded in retaining their valuable employees. The decrease of turnover rate can easily be minimized.

Findings: The survey questionnaire findings for the above assumption have revealed that the above hypothetical statement is inversely proportional to each other. They are very strongly and inversely bonded together. If work satisfaction is fulfilled then the turnover intentions minimizes greatly and vice versa. For salary issue, $78 \%$ of the respondents of age group agree with the question related to salary issue and rest disagrees. $69 \%$ of the respondents of education category agree. $62 \%$ from the job category, $71 \%$ of the respondents from income level and $68 \%$ from experience category agrees that salary issues can bring motivation among the employees and provide satisfaction in the job. The other question asked was the positive and constructive role of the management in order to provide satisfaction with the job. $72 \%$ respondent of age, $75 \%$ of the education, $82 \%$ of the job, $63 \%$ from the income level and $83 \%$ of the respondents from the experience group agree with the idea and the rest disagreed. Next question in this regard was asked about the worse working environment and the respondents recorded $71 \%$ from age, $77 \%$ from education, $67 \%$ from the job, $79 \%$ from the income level and $82 \%$ from the experience category agree with the question and the rest disagreed. Hence the responses of the respondents validate the above assumption strongly correct.

\section{H3: Job commitment and employee turnover have positive} impact on organizational productivity

The literature and results of the survey clearly suggest that if the workers or the people working in organization feel satisfied with what they had and duties they have to perform then nothing will stop the organization to thrive. Many literature and research articles prove this relationship and in the current also validate that if the employees are satisfied they give their full commitment to their job and in that case they work hard and result would come in increased level of production. The relationship of job satisfaction and job commitment is directly connected. If there is increase in job contentment there is increase in job commitment and it increase more with the increase of satisfaction level. The result of both will leads towards increase in productivity. This attitude and behavioural change in employees can automatically affect the intentions of quitting or leaving jobs. They spend their time in increasing and improving their performance level rather than looking for other opportunities. However the relation between intentions of employee turnover and improved productivity level are inversely proportional to each other. No studies proved the connection between these two as positive.

Findings: The findings and detailed survey regarding hypothesis was proved wrong. It was found that indirect relation exists between the commitment of work and turnover aims of employees. If the commitment towards job and organization increases the turnover rate would be at minimum side and vice versa. Commitment towards job and increased productivity are positively related to each other but negatively related to employee turnover. To prove this correlation, the first question asked in this regard was that better job opportunities lead to high turnover rate and about $61 \%$ respondents of age group, $72 \%$ of education, $69 \%$ job, $85 \%$ income level and $79 \%$ of the experience group agree with the idea and the rest disagree with the question asked. The next question asked was about the prospects for future development has direct connection with the employee turnover intentions. About $13 \%$ of the age group respondents agree with the question,09\% education, $11 \%$ job, $08 \%$ income level and $04 \%$ of the experience group agrees but the rest greatly disagree and disapprove such intentions. Hence the above assumption showed failure in proving the optimistic relation between job commitment and employee turnover aims with that of improved and enhanced productivity.

H4: Attractive job prospects have direct impact on employee turnover

Lucrative job opportunities serve as a major distraction for employees. The employees in the organization whether fresh graduates or experienced personnel, they all leave their existing jobs if better jobs with attractive packages and perks offered from elsewhere. Leaving of the valuable human asset from any organization can give severe setback. This situation became more detrimental for the organization if there were no plan of succession and replacing of employees exist.

Findings: The findings of the survey suggest that there is a direct connection between the attractive job opportunity and employee turnover but wherever interest is taken by the management, excellent working environment is provided to them, the result would be opposite. The survey conducted for, and found interesting results. Excellent working environment helps the employer to have more committed employees, $78 \%$ respondents of age, $62 \%$ of education, $59 \%$ of job, $61 \%$ of income level and $69 \%$ of experience group agree with the question asked. For the second question, about $72 \%$ respondents of age, $71 \%$ education, $65 \%$ job, $57 \%$ of income level and $75 \%$ of experience group agree with the idea of the question. The third and the last question asked and about $78 \%$ of age, $81 \%$ of the education, $90 \%$ of the job $76 \%$ of the income level and $89 \%$ of the experience group greatly agrees with it that lack of interest shown by the management towards employees and their work would ultimately result in losing their trustable and committed workers very often. Whenever attractive offers come their way the employees definitely go for it thus raising the bar of employee turnover.. Therefore, it has been notice that there is a direct relation between the two and hence the hypothesis is proved right.

\section{Discussion and Conclusion}

The primary aim of this research paper was to identify the determinants of turnover aims of employees from the organization and the degree to which it relate to the determinants. It was interesting to search the determinants that trigger an employee towards leaving and switching jobs especially in the urban society of Pakistan. There were numerous reason came in front however this study only focus on core basic reasons if not fulfilled than might develop demotivating phase among the employees. Pakistan metro city Karachi has been taken as the case study of this research study. The focus of this paper was to identify the reasons and determinants of employee turnover intentions and aims to highlight their degree of relationship with each other and their impact. The result perceived might little bit differ from other cities of Pakistan because the research was conducted solely on the bankers working in Karachi.

The survey questionnaire was designed to cover and validate four hypotheses. Set of questions were asked to determine the relation of employee turnover intentions with that of work satisfaction, work commitment, boss-subordinate relation and work opportunities. Job satisfaction showed inverse relation with that of turnover aims of employees. It was also noted that if satisfaction level minimizes by 
any how the turnover aims shown by the employee would be creeping towards maximum side. The previous studies also have the same kind of findings. Boss-subordinate pair would deliver excellent work if coordinated and complemented well to each other and vice versa.

The result in the survey regarding how the pair of boss-subordinate affects the employee turnover aims was very clear. It was observed and validated from the result of the survey that boss-subordinate pair has strong and inverse kind of relation. If subordinate and boss are well connected, coordinated, maintained good working relationship then the employee's turnover rate would be at its least level and vice versa. However the results of job commitment in relation to turnover aims showed modest kind of relation. In contrast to this the results of job opportunity with that of turnover rate with the banking professionals of urban areas of Pakistan revealed that they have strong connection and exert immense impact on turnover rate. Unlike the studies done by the earlier researchers on this relationship were totally opposite. These determinants were not found as important in affecting the turnover intentions as job satisfaction and boss-subordinate relations have. The difference observed in the current survey questionnaires with that of the previous studies on the same determinants might be because of the respondent's professional background, cultural difference and hierarchical position, approaches and perception alteration etc.

The study has varying connotations for managers and part of organization as well because this study was conducted in Karachi only. So there might some difference in findings and evaluation of results. The current practices regarding Human Resources need to be made favourable for the workers and employees. Skill inventory and managerial inventory need to be updated from time to time. Succession planning should also revise as per the performance and skill sets of the employees.

Managers show their good gestures and cooperation with good leadership style in order to keep their subordinates motivated. The bank professionals need to be given good perks and benefits which should be market compatible. There lots of other determinants also found during this study however it was impossible to cover all those aspects of turnover intentions of the employees. Other researchers have good opportunity to explore more determinants and aspects of conducting the research studies on the same ground as well. This study will help managers and employers of any organization to address the grievances, issues and problems of the employees. They need to stretch their professional guidance support and cooperation to retain and intact their valuable employees and help them in building their life long career with them and contribute constructively in the success of the organization.

\section{References}

1. Ivancevich J, Olelans M, Matterson MT (1997) Organizational Behavior and Management, Sydney: Irwin.

2. Davis K, Newstrom J (1999) Comportamiento Humano en el Trabajo: Comportamiento Organizaciona (10th Edn). Mexico: McGraw-Hill.

3. Kevin MM, Joan LC, Adrian JW (2004) Organizational change and employee turnover. Personnel Rev 33: 161-166.

4. Stovel M, Bontis N (2002) Voluntary turnover: knowledge management-friend or foe? J intellect Cap 3: 303-322.

5. Abassi SM, Hollman KW (2000) Turnover: the real bottom line. Public Personnel Management 2: 333-342.

6. Bluedorn AC (1982) A unified model of turnover from organizations. Hum Rela 35: $135-153$

7. Kalliath TJ, Beck A (2001) Is the path to burnout and turnover paved by a lack of supervisory support: a structural equations test. New Zealand J Psychol 30 $72-78$

8. Kramer MW, Callister RR, Turban DB (1995) Information-receiving and information-giving during job transitions. West J Commun 59: 151-70.

9. Peters L, Bhagat R, O'Connor EJ (1981) An examination of the independent and joint contribution of organizational commitment and job satisfaction on employee intention to quit. Group Org Studies 6: 73-82.

10. Firth L, Mellor DJ, Moore KA, Loquet C (2007) How can managers reduce employee intention to quit? J Manage Psychol 19: 170-187.

11. Markow K, Klenke K (2005) The effects of Personal meaning and calling on Organizational Commitment: An empirical investigation of Spiritual Leadership. Int J Org Ana 13: 8-27.

12. Milliman J, Czaplewski AJ, Ferguson J (2003) Workplace spirituality and employee work attitudes: an exploratory empirical assessment. J Org Chan Manage 16: 426-447.

13. Khatri N, Fern CT, Budhwar P (2001) Explaining employee turnover in an Asian context. Human Resource Management Journal 11: 54-74.

14. Korunka C, Hoonakker PLT, Carayon P (2005) A Universal Turnover Model for the IT Work Force - A Replication Study, pp: 467-472.

15. Harrell A, Chewning E, Taylor M (1986) Organizational-Professional Conflict and the Job Satisfaction and Turnover Intentions of Internal Auditors. Auditing A Journal of Practice \& Theory 5: 109-121.

16. Chen TY, Chang PL, Yeh CW (2004) A Study of Career Needs, Caree Development, Job Satisfaction and the Turnover Intentions of R\&D Personnel. Career Development International 9: 424-437.

17. Brough P, Frame P (2004) Predicting Police Job Satisfaction and Turnover Intentions: The role of Social Support and Police Organizational Variables. New Zealand Journal of Psychology 33: 8-16.

18. Hackman JR (1980) Work Redesign and Motivation. Professional Psychology 11: $445-455$.

19. Karsh B, Booske BC, Sainfort F (2005) Job and Organizational Determinants of Nursing Home Employee Commitment, Job Satisfaction and intent to Leave. Ergonomics 48: 1260-1281.

20. Guimaraes T, Igbaria M (1992) Determinants of Turnover Intentions: Comparing IC and IS Personnel. Information Systems Research 3: 273-303.

21. Aryee S, Wyatt T, Min MA (1990) Antecedents of Organizational Commitment and Turnover Intentions Among Professional Accountants in Different Employment Settings in Singapore. The Journal of Social Psychology 131 545-556.

22. Van DR, Christ O, Stellmacher J, Wagner U, Ahlswede O, et al., (2004) Should I Stay or Should I Go? Explaining Turnover Intentions with Organizational Identification and Job Satisfaction. British Journal of Management 15: 351-360.

23. Sjoberg A, Sverke M (2000) The Interactive Effect of Job Involvement and Organizational Commitment on Job Turnover Revisited: A Note on the Mediating role of Turnover Intention. Scandinavian Journal of Psychology 41 247-252.

24. Morrison RL (2004) Informal Relationships in the Workplace: Association with Job Satisfaction, Organizational Commitment and Turnover Intentions. New Zealand journal of Psychology 33: 114-128.

25. Bloom N, Van Reenen J (2007) Measuring and explaining management practices across firms and countries. Quart J Econ 122: 1351-1408.

26. Sels L, De Winne S, Maes J, Delmotte J, Faems D, et al., (2006) Unravelling the HRM-performance link: Value-creating and costincreasing effects of small business HRM. J Manage Stud 43: 319-342.

27. Petrescu Al, Simmons R (2008) Human resource management practices and workers' job satisfaction. Int J Manpower 29: 651-667.

28. Howard MH, Homma M (2001) Job Satisfaction of Japanese Career Women and its Influence on Turnover Intention. Asian Journal of Social Psychology 4: 23-38.

29. Samad S (2006) Predicting Turnover Intentions: The Case of Malaysian Government Doctors. The Journal of American Academy of Business 8: 11131119 . 
Citation: Mumtaz R, Hasan SS (2018) Determinants of Employee Turnover A Survey of Employee Intentions Trend in Urban Societies of the Region. Bus Eco J 9: 356. doi: 10.4172/2151-6219.1000356

Page 8 of 8

30. Moncrief WC, Cravens DW, Johnston M (1996) Examining the antecedents and Consequences of Salesperson Job Stress. European Journal of Marketing 31: $786-798$

31. Elangovan AR (2001) Casual Ordering of Stress, Satisfaction and Commitment and intention to Quit: A Structural Equation Analysis. Leadership \& Organization Development Journal 22: 159-165.

32. Negrin RM, Tzafrir SS (2004) Job Search Modes and Turnover. Career Development International 9: 442-458.

33. Ing-San H, Jyh-Huei K (2006) Effects of Job Satisfaction and Perceived Alternative Employment Opportunities on Turnover Intention - An Examination of Public Sector Organizations. Journal of American Academy of Business 8: 254-269.

34. Lambert EC, Hogan NL, Barton SM (2001) The impact of job Satisfaction on Turnover Intent; A Test of a Structural Measurement Model Using a National Sample of workers. The Social Science Journal 38: 233-250.

35. Thatcher JB, Stepnia LP, Boyle RJ (2003) Turnover of Information Technology Workers: Examining Empirically the Influence of Attitudes, Job Characteristics and External Markets. Journal of Management Information Systems 19: 231-261.

36. Schervish PG (1983) The structural Determinants of unemployment, Vulnerability and power in market relations. academic press, New York, pp: $71-112$
37. Idson TL, Feaster DJ (1990) A selectivity model of employer-size wage differentials. J. Labor Econ 8: 99-122.

38. Trevor C (2001) Interactions among actual ease-of-movement determinants and job satisfaction in prediction of voluntary turnover. Acad Manage $\mathrm{J} 44$ 621-638.

39. Booth S, Hamer K (2007) Labour turnover in the retail industry: Predicting the role of individual, organisational and environmental factors. The Inte $\mathrm{J}$ Retail Distribution Manage 35: 289-307.

40. Zuber A (2001) A career in food service cons: high turnover. Nations Restaurant News 35: 147-148.

41. Labov B (1997) Inspiring employees the easy way. Incentive 171: 114-118.

42. Magner N, Welker R, Johnson G (1996) The interactive effects of participation and outcome favorability in performance appraisal on turnover intentions and evaluations of supervisors. J Occupational Org Psychol 69: 135-143.

43. Locke E (1976) The nature and causes of job satisfaction. In Dunnette MD (Eds). Handbook of Industrial and Organizational Psychology, Rand McNally, Chicago, pp: 1297-1349.

44. Phillips DJ (1990) The price tag on turnover. Pers. J, pp: 58-61 